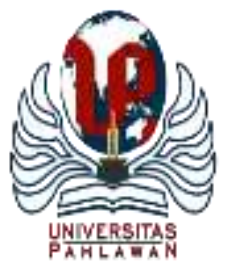

Edukatif : Jurnal Ilmu Pendidikan Volume 3 Nomor 6 Tahun 2021 Halm 5150 - 5160

EDUKATIF: JURNAL ILMU PENDIDIKAN

Research \& Learning in Education

https://edukatif.org/index.php/edukatif/index

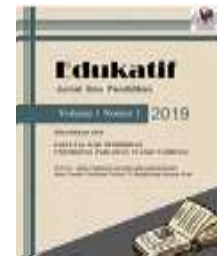

\title{
Hubungan Regulasi Emosi dan Konformitas Teman Sebaya dengan Perilaku Agresi di Pontianak
}

\author{
Sita Permatasari ${ }^{1 凶}$, Nina Zulida Situmorang ${ }^{2}$, Triantoro Safaria ${ }^{3}$ \\ Universitas Ahmad Dahlan, Indonesia ${ }^{1,2,3}$ \\ E-mail : sitha.permatasari@gmail.com ${ }^{1}, \underline{\text { nina.situmorang@psy.uad.ac.id }}^{2}, \underline{\text { triantoro.safaria@psy.uad.ac.id }}^{3}$
}

\begin{abstract}
Abstrak
Penelitian ini bertujuan untuk mengetahui hubungan antara regulasi emosi, konformitas teman sebaya dengan perilaku agresi pada siswa SMK di Pontianak. Subjek dalam penelitian ini adalah 120 siswa. Teknik pengambilan sampel dalam penelitian menggunakan cluster random sampling. Alat ukur yang digunakan adalah skala regulasi emosi, konformitas teman sebaya, dan skala perilaku agresi. Pengambilan data penelitian melalui google form yang disebarkan secara online. Data penelitian ini dianalisis menggunakan teknik regresi berganda dengan menggunakan program Statistical Product and Service Solusion for windows 26.0. Berdasarkan hasil analisis regresi berganda di peroleh nilai F Change sebesar 15, 496 dengan taraf signifikansi $0,000(\mathrm{p}<0,01)$ yang sangat signifikan. Artinya ada hubungan negatif yang sangat signifikan antara regulasi emosi, dan komformitas teman sebaya terhadap perilaku agresi pada siswa SMK di Pontianak. Ada hubungan regulasi emosi dengan perilaku agresi pada siswa SMK di Pontianak, hal tersebut ditunjukkan dengan nilai t sebesar -3,642 dengan taraf signifikasi sebesar 0,009 ( $p>0,05)$. Ada hubungan konformitas teman sebaya dengan perilaku agresi pada siswa SMK di Pontianak, hal tersebut ditunjukkan dengan nilai t sebesar 4,173 dengan taraf signifikasi $0,008(\mathrm{p}<0,05)$.
\end{abstract}

Kata Kunci: regulasi emosi, konformitas teman sebaya, perilaku agresi, perundungan

\begin{abstract}
This study aims to determine the relationship between emotional regulation peer conformity with aggressive behavior in vocational students in Pontianak. The subjects in this study were 120 students. The sampling technique in this study used cluster random sampling. The measuring instrument used is the emotional regulation scale, peer conformity, and aggressive behavior scale. Retrieval of research data through Google form which is distributed online. The research data were analyzed using multiple regression techniques using the Statistical Product and Service Solution for Windows 26.0 program. Based on the results of multiple regression analysis, the $F$ Change value is 15, 496 with a significance level of 0.000 ( $p<0.01)$ which is very significant. This means that there is a very significant negative relationship between emotion regulation, and peer conformity to aggressive behavior in vocational students in Pontianak. There is a relationship between emotional regulation and aggressive behavior in SMK students in Pontianak, it is indicated by the $t$ value of 3.642 with a significance level of 0.009 ( $p>0.05)$. There is a relationship between peer conformity and aggressive behavior in SMK students in Pontianak, it is indicated by a t-value of 4.173 with a significance level of $0.008(p<0.05)$.
\end{abstract}

Keywords: Emotion regulation, Peer conformity, Aggressive behavior, Bullying

Copyright (c) 2021 Sita Permatasari, Nina Zulida Situmorang, Triantoro Safaria

$\triangle$ Corresponding author:

Email : sitha.permatasari@gmail.com

DOI $\quad:$ https://doi.org/10.31004/edukatif.v3i6.1422

ISSN 2656-8063 (Media Cetak)

ISSN 2656-8071 (Media Online)

Edukatif : Jurnal Ilmu Pendidikan Vol 3 No 6 Tahun 2021 p-ISSN 2656-8063 e-ISSN 2656-8071 
5151 Hubungan Regulasi Emosi dan Konformitas Teman Sebaya dengan Perilaku Agresi di Pontianak - Sita Permatasari, Nina Zulida Situmorang, Triantoro Safaria

DOI: https://doi.org/10.31004/edukatif.v3i6.1422

\section{PENDAHULUAN}

Orientasi sekolah adalah bagaimana menciptakan siswa-siswa atau generasi yang cerdas, bertanggungjawab, jujur dan berahklak mulia. Sekolah merupakan sebuah lembaga yang bertujuan untuk membangun orientasi tersebut dengan tidak merugikan pihak manapun. Tak jarang pihak sekolah harus menghadapi banyak masalah dan tantangan untuk mewujudkannya. Masalah yang paling krusial adalah agresivitas, kenakalan remaja bahkan kecenderungan untuk melakukan kekerasan semakin meningkat (Sentana and Kumala 2017). Perilaku agresif merupakan suatu luapan emosi yang ditampakkan dengan pengrusakan pada diri sendiri, orang lain, maupun sarana publik sebagai bentuk kegagalan individu secara sadar atau sengaja yang dieskpresikan dengan kata-kata dan perilaku (non verbal). Contoh dari perilaku agresif remaja yang terlihat jelas adalah semakin banyaknya berita yang disajikan setiap hari di media masa baik cetak maupun elektronik tentang perilaku kekerasan remaja baik secara individual maupun secara berkelompok, seperti tawuran, penganiayaan, penyiksaan, bahkan sampai menghilangkan nyawa (Trisnawati dkk, 2014). Misalnya di Banda Aceh seorang remaja yang berusia 17 tahun menusuk temannya dengan motif cemburu. Sekelompok remaja lainnya yang berusia dibawah 17 tahun menikam dan menganiaya mahasiswa. Dengan perasaan kesal dan amarah, mereka melakukan tindakan kekerasan tersebut. Ditinjau dari berita detik.com (2019) telah menimbulkan satu orang pelajar berinisial DA usia 16 tahun.

Korban dibacok dengan menggunakan senjata tajam oleh sekelompok remaja lainnya. Salah satu rekannya tidak diterima dengan ejekan orang lain sehingga seluruh anggota kelompok marah dan kembali membalas perlakuan orang lain dengan pembacokan. Kasus ini membuat sebagian pihak tidak setuju dan memasukkannya ke dalam kategori perilaku agresivitas. Perilaku agresivitas mengarah pada tingkat yang tinggi (Pratiwi dkk, 2019). Hal tersebut ditandai dari banyaknya praktik agresi yang tidak dibenarkan seperti tawuran, pemalakan, bullying, pemerkosaan hingga di fase pembunuhan. Kasus yang ditemukan Li dkk (2021) bahwa 40\% siswa usia 13-15 tahun mendapatkan kekerasan fisik oleh teman sebaya dan $75 \%$ siswa pernah mengakui melakukan kekerasan di sekolah. Aksi kekerasan ditunjukkan oleh siswa di Yogyakarta. Dari hasil penelitian Puspawardhani (2021) kasus agresivitas yang sering terjadi adalah kemarahan, permusuhan, fisik dan agresivitas verbal. Selain itu, aktivitas memukul, mencubit, mendorong, melempar bola-bola dari kertas, mengejek nama orang tua, menyindir dan membentak masih sering bermunculan di kalangan siswa. Individu tidak mampu mengontrol emosinya sehingga menyebabkan perilaku agresi meningkat. Tingginya angka agresivitas pada siswa SMA di Jakarta Pusat sebanyak 6,9\% (Fitri dkk, 2016). Hal tersebut dicirikan dengan permusuhan antar pribadi. Individu menyimpan dendam, marah, benci, tidak percaya, khawatir dan perasaan negatif lainnya terhadap orang lain akibatnya individu bertindak agresi ketika ada masalah sepele.

Masalah sepele bisa menjadi pemicu timbulnya agresivitas seperti dalam hasil wawancara dengan salah satu guru di SMK X Pontianak bahwa siswa X berkelahi mulut sama teman sekelasnya dan pernah bully teman sekelasnya dengan alasan bercanda. Siswa Y juga mengaku pernah membully temannya karena tidak suka dengan perlaku temannya tersebut. Individu merasa perkataan orang lain menyakitkan baginya sehingga ada keinginan untuk membalas perbuatannya. Salah satu contohnya, pada sekolah yang berbeda di SMK X Pontianak ditemukan perkelahian antar pelajar. Penyebabnya adalah salah satu teman yang menyebarkan gosip yang tidak benar terhadap dirinya. Hal serupa juga di alami oleh siswa Y menyatakan bahwa dirinya pernah terlibat pertengkaran mulut, dan saling mendorong badan. Siswa $Z$ yang di wawancarai mengakui pernah mengejek-ngejek teman yang tidak pernah melakukan kesalahan terhadap dirinya, bagi mereka itu hanya bercanda, dan tidak masalah walaupun teman yang di ejek merasa tidak nyaman.

Perilaku agresif membuat dampak yang serius bagi pelaku maupun korban. Dari korban bisa menjadi pelaku dan bertindak lebih agresif dibandingkan orang lain. Dampak psikis dan fisik terlihat jelas pada individu. Dimulai dari sulitnya mengontrol emosi, coping yang dimiliki kurang baik sehingga mengalihkan masalahnya pada obat-obatan terlarang dan perilaku menyimpang (Trisnawati, dkk 2014). Emosi yang tidak 
stabil, dan tidak mampu menahan hawa nafsu membuat individu lebih agresif (Trisnawati dkk, 2014). Sedangkan faktor yang menyebabkan terjadinya perilaku agresif pada remaja yaitu faktor internal (dari dalam) maupun faktor eksternal (dari luar). Faktor internal tersebut meliputi: frustasi, gangguan pengamatan, tanggapan remaja, gangguan berfikir dan intelegensi remaja, serta gangguan perasaan/emosional remaja sedangkan faktor eksternal meliputi faktor keluarga, faktor sekolah, faktor teman sebaya dan faktor lingkungan (Noviadi dkk, 2018). Reaksi emosional yang berlebihan mempengaruhi persepsi individu. Kemudian, untuk meminimalisir agresivitas kelompok maka faktor yang berperan disini adalah regulasi emosi.

Wardah (2020) menjelaskan bahwa terdapat pengaruh regulasi emosi terhadap perilaku agresif pada korban bullying. Tingkat agresivitas semakin menurun dengan pengaruh faktor internal yakni regulasi emosi. Terbukti, dari hasil penelitian Prasetio dkk (2021) bahwa terdapat hubungan yang signifikan antara regulasi emosi dengan perilaku bullying. Yang dimana perilaku bullying termasuk salah satu contoh konkret dari perilaku agresif. Hipotesis yang sama juga diajukan oleh Purwadi, dkk (2020) bahwa terdapat pengaruh regulasi emosi terhadap perilaku agresif pada remaja. Dengan hasil final bahwa terdapat pengaruh signifikan yang berarti bahwa regulasi emosi merupakan faktor penting yang mungkin bisa untuk mengendalikan agresi terhadap siswa. Semakin baik kemampuan individu untuk mengatur emosi, kemungkinan besar individu mendapatkan kesempatan untuk berkurangnya agresivitas. Sebaliknya, semakin buruk kemampuan seseorang untuk mengatur emosi, potensi orang tersebut untuk mengembangkan agresi meningkat.

Faktor internal yang menyebabkan perilaku agresif ini pernah diteliti oleh (Thohar 2018) adalah regulasi emosi sebesar 0,301 yang dimana semakin tinggi regulasi emosi maka semakin rendah perilaku agresivitas. Regulasi emosi membantu individu untuk memulihkan kembali keseimbangan emosi meskipun pada awalnya seseorang kehilangan kontrol atas emosi yang dirasakannya. Selain itu, seseorang hanya dalam waktu singkat merasakan emosi yang berlebihan dan dengan cepat menetralkan kembali pikiran, tingkah laku, respon fisiologis dan dapat menghindari efek negatif akibat emosi yang berlebihan. Adapun ciri-ciri individu yang dapat melakukan regulasi emosi dengan baik ialah memiliki kendali diri, hubungan interpersonal yang baik, sikap hati-hati, mudah beradaptasi, toleransi terhadap frustasi, pandangan yang positif, peka terhadap perasaan orang lain, melakukan introspeksi dan relaksasi, lebih sering merasakan emosi positif daripada emosi negatif serta tidak mudah putus asa. Kemunculan regulasi emosi sangat efektif dalam menyikapi perilaku agresif (Roberton dkk, 2012).

Kecenderungan individu untuk menyerang atau menyakiti orang dengan tujuan tertentu dipengaruhi oleh konformitas teman sebaya. Sesuai dengan tinjauan Prayugo dan Suroso (2018) pengaruh konformitas teman sebaya terhadap perilaku agresif terbukti ada. Hasilnya menyebutkan bahwa individu menyesuaikan diri dengan pola pikir, kebiasaan, nilai-nilai yang dianut, satu pemahaman yang positif dalam kelompok sehingga individu tidak melakukan tindakan-tindakan agresi. Individu percaya dengan kelompoknya yang dominan positif sehingga sangat memungkinkan pengaruh teman sebaya membuat individu lebih berpikir positif dan berkawan baik. Konformitas teman sebaya berpengaruh terhadap cara pandang dan bertindak individu, seperti dalam penelitian. Hasil penelitian yang berbeda diungkapkan oleh Sovitriana dkk (2020) dimana hubungan konformitas teman sebaya dan agresif berkorelasi positif yang menandakan bahwa semakin tinggi konformitas teman sebaya maka semakin tinggi pula perilaku agresif individu.

Penelitian tersebut senada dengan hasil tinjauan Palinoan dkk (2015) bahwa terdapat hubungan yang kuat antara konformitas terhadap perilaku agresivitas pada kelompok geng motor di Samarinda. Kekuatan dari lingkungan dan teman yang berpikiran positif adalah tingkat agresivitas rendah. Sejalan dengan hasil penelitian Retnowuni dan Linda Yani (2019) adanya pengaruh teman sebaya terhadap perilaku agresif remaja di Pondok Pesantren. Pengaruh konformitas teman sebaya tergantung dari sikap dan persepsi yang berkaitan dengan gaya hidup seseorang. Kelompok membentuk nilai-nilai positif seperti mengedepankan nilai-nilai kejujuran, keadilan, kesopanan, dan kedisiplinan. Dengan hal tersebut, individu berkembang menjadi pribadi 
5153 Hubungan Regulasi Emosi dan Konformitas Teman Sebaya dengan Perilaku Agresi di Pontianak - Sita Permatasari, Nina Zulida Situmorang, Triantoro Safaria

DOI: https://doi.org/10.31004/edukatif.v3i6.1422

yang lebih baik dan lebih optimis. Sebaliknya, jika kelompok remaja menunjukkan sikap negatif maka mempengaruhi mental dengan membuat pribadi individu tidak baik, dilabel pembuat masalah bahkan lingkungan sekitar menolak kehadirannya.

Individu sangat mudah terpapar dengan teman sebaya, media sosial, media elektronik ucapan orang lain, atau yang ditontonnya. Kemungkinan terburuknya adalah individu meniru atau mencontohkan perilaku atau ucapan orang lain dengan sengaja dan bertindak agresif (Sovitriana dkk, 2020). Konformitas teman sebaya dan perilaku agresif jika berkorelasi positif maka dapat dikatakan konformitas tersebut berbentuk negatif. Studi terbaru menjelaskan bahwa terdapat hubungan positif konformitas teman sebaya dengan agresivitas remaja pada siswa SMAN 3 Denpasar. Konformitas terjadi pada remaja karena adanya kebutuhan untuk diterima oleh kelompok sosial, semakin tinggi keinginan dari individu untuk diterima oleh kelompok sosial maka semakin tinggi pula konformitas pada individu (Raviyoga and Marheni 2019).

Bentuk perilaku negatif yang sengaja didesain dalam kelompok seperti berbicara dengan bahasa asalasalan, mencuri, mencoret-coret prasarana, mempermainkan orang yang lebih tua dan berperilaku agresif. Beberapa siswa menganggap perilaku tersebut sebagai hal yang bisa dimaklumi dalam kelompok dan merasa dituntut oleh lingkungan. Konformitas kelompok dapat memunculkan perilaku tertentu pada seseorang, perilaku tersebut dapat bersifat positif maupun negatif. Perilaku negatif yang dimungkinkan muncul karena konformitas adalah perilaku agresif, seperti kerusuhan dan tawuran. Kuatnya pengaruh kelompok akan mempengaruhi perilaku dan sifat konformis pada diri remaja. Dalam kaitannya dengan perilaku agresif, remaja yang memiliki konformitas yang tinggi akan memiliki perilaku agresif yang tinggi, sedangkan remaja yang memiliki konformitas yang rendah, memiliki perilaku agresif yang rendah pula (Palinoan dkk, 2015).

Perilaku agresivitas menjadi momok bagi sebagian orang. Perilaku agresivitas diteliti dari karakteristiknya yakni verbal, fisik, kemarahan dan permusuhan. Perilaku agresivitas dapat memasuki setiap fase dalam aktivitas individu. Individu mudah marah, mudah cemburu, merusak barang, mudah curiga, mengancam orang lain, jengkel melihat teman berprestasi, berbicara kasar, berteriak-berteriak, membalas dengan pukulan keras, mengejek orang lain merupakan serangkaian perilaku agresif yang diobservasi dalam penelitian ini. Karakteristik agresi perlu direduksi dengan faktor pendukung eksternal maupun internal. Dengan faktor internal yakni regulasi emosi seperti tenang, sabar, menolong, meminta maaf dan lain sebagainya diharapkan mampu menurunkan angka agresivitas di Pontianak. Faktor eksternal dibutuhkan yakni konformitas teman sebaya seperti berteman dengan cara positif, tidak menghasut kepada keburukan, menerapkan nilai-nilai yang tidak bertentangan norma atau aturan sekolah dan lain sebagainya diharapkan mampu mengurangi agresivitas remaja.

Perilaku agresivitas perlu ditinjau lebih dalam melalui penelitian yang komprehensif. Untuk itu, diperlukan variabel-variabel yang dapat mengatasi perilaku agresivitas. Melalui penelitian ini, peneliti mengaitkan regulasi emosi dan konformitas teman sebaya untuk mempengaruhi perilaku agresivitas siswa di Pontianak. Penelitian ini bertujuan untuk mengetahui "Hubungan Regulasi Emosi dan Konformitas Teman Sebaya dengan Perilaku Agresi di Pontianak". Adapun rumusan masalah yang dikemukakan dalam penelitian ini adalah apakah ada pengaruh antara regulasi emosi, dan konformitas teman sebaya pada perilaku agresi di Pontianak.

\section{METODE PENELITIAN}

Tahapan pertama adalah menentukan jenis penelitian. Penelitian ini mengadaptasi jenis kuantitatif nonexperiment. Uji yang dilakukan adalah statistika parametrik. Acuan yang digunakan adalah jika semua data berdistribusi normal maka menggunakan data parametrik. Sebaliknya, jika data tidak berdistribusi nomal maka data dianalisis dengan statistika non-parametrik (Azwar 2015). Penelitian ini disertai dengan SPSS versi 20. Teknik sampling yang digunakan adalah simple random sampling dengan total 120 siswa SMK X di Pontianak. Pengambilan data penelitian dilakukan secara online dan dibantu oleh wali kelas masing-masing. 
Peneliti menghubungi wali kelas melalu media sosial whatsapp dimana peneliti memberikan skala melalui link google forms ke wali kelas kemudian wali kelas menyebar link google forms ke group kelas yang sudah ditentukan. Siswa laki-laki sebanyak 41 dan siswa perempuan berjumlah 79 dengan rentang usia 15-17 tahun.

Method of summated ratings merupakan metode yang dilakukan dan diartikan dengan mentransformasi jenjang pilihan jawaban ordinal menjadi kuantitas berskala interval. Metode skala mengasumsikan bahwa subjek penelitian adalah orang yang paling tahu tentang dirinya sendiri sehingga jawaban yang diberikan oleh subjek dapat dipercaya dan sesuai dengan tujuan penelitian. Model skalanya adalah skala Likert sebagai instrumen pendukung penelitian. Alternatif jawaban yang disediakan ada empat yakni sangat setuju, setuju, tidak setuju, dan sangat tidak setuju. Setiap variabel memiliki dua kategori utama yakni aitem-aitem favorable dan aitem-aitem unfavorable. Pengertian aitem favorabel merupakan aitem yang mendukung atau mewakili variabel sedangkan aitem unfavorabel merupakan aitem yang tidak mendukung atau dapat mendistorsi jawaban subjek. Skala yang disusun adalah skala agresivitas, skala regulasi emosi dan skala konformitas teman sebaya. Sebelum diberikan kepada subjek, peneliti melakukan uji coba skala. Hal ini diperlukan untuk mengeliminasi aitem yang dikategorikan sebagai tidak memuaskan dikarenakan hasil estimasi reliabilitas pada sisa aitem setelah dilakukan eliminasi bertahap terhadap aitem-aitem yang tidak mencapai kriteria koefisien korelasi aitem-total rix $=0,15$; rix=0,20; rix $=0,25$; dan rix $=0,30$ (Azwar 2009).

Pertama, skala agresivitas terdiri dari 12 aitem. Untuk skala regulasi emosi berjumlah 10 aitem. Selanjutnya, skala ketiga yakni skala konformitas teman sebaya jumlah aitem yang dapat digunakan sebanyak 20 aitem. Skala perilaku agresi memiliki koefisien reliabilitas alpha $(\alpha)$ sebesar 0,821 , Skala regulasi emosi memiliki koefisien reliabilitas alpha $(\alpha)$ sebesar 0,814 dan Skala konformitas teman sebaya memiliki koefisien reliabilitas alpha $(\alpha)$ sebesar 0,893 . Peneliti menunggu respon subjek mengisi skala secara online dan meminta subjek mengkonfirmasi di group kelas bila sudah selesai mengerjakan skala tersebut yang kemudian wali kelas memberitahu peneliti. Setelah skala sudah terkumpul, peneliti melakukan skoring dan menganalisis data dengan bantuan komputer program SPSS 20.00 for windows. Selain mencari uji reabilitas dan validitasnya, peneliti memenuhi uji asumsi sebagai prasyarat menentukan hipotesis diterima ataupun ditolak. Uji asumsi terdiri dari uji linieritas, normalitas dan multikolinearitas. Sedangkan uji hipotesisnya menggunakan analisis regresi berganda.

\section{HASIL DAN PEMBAHASAN PENELITIAN}

Temuan pertama adalah data berdistribusi normal yang masing-masing variabel perilaku agresi nilai $\mathrm{p}>0,140$, regulasi emosi nilai $\mathrm{p}>0,312$, dan konformitas teman sebaya nilai $\mathrm{p}>0,129$. Kemudian, ditemukan bahwa semua data dinyatakan linier. Hasil yang diperoleh dari uji linearitas pada variabel regulasi emosi dan perilaku agresi menunjukkan bahwa $F_{\text {Linearity }}=11,801$ dan $F_{\text {Deviation from Linearity }}=1,047$. Hasil yang diperoleh dari uji linieritas pada variabel konformitas teman sebaya dan perilaku agresi menunjukkan bahwa $F_{\text {Linearity }}=16.481$ dan $F_{\text {Deviation from Linearity }}=1.188$. diperoleh juga Sig linearity $=0,000$ dan $\operatorname{Sig}_{\text {Deviation of linearity }}=0,282$. Selanjutnya, uji multikolinearitas dideskripsikan dengan variabel regulasi emosi memiliki nilai VIF (Varience Inflation Factor) sebesar $1.000(<10)$ dan nilai Tolerance sebesar 1,000 $(>0.1)$, dan konformitas teman sebaya memiliki milai VIF (Varience Inflation Factor) sebesar 1,000 (<10) dan nilai Tolerance sebear 1,000 ( $>0.1)$ sehingga dapat disimpulkan tidak terjadi multikolinearitas. Asumsinya telah terpenuhi sehingga dapat dilanjutkan uji hipotesis. Hipotesis mayor berbunyi terdapat hubungan signifikan secara bersama-sama antara regulasi emosi dan konformitas teman sebaya terhadap perilaku agresif di Pontianak, maka penjelasannya dapat dilihat pada tabel dibawah ini: 
5155 Hubungan Regulasi Emosi dan Konformitas Teman Sebaya dengan Perilaku Agresi di Pontianak - Sita Permatasari, Nina Zulida Situmorang, Triantoro Safaria

DOI: https://doi.org/10.31004/edukatif.v3i6.1422

Tabel 1

Hasil Analisis Regresi Berganda

\begin{tabular}{llllll}
\hline $\mathrm{R}$ & R square & Adjusted R square & \multicolumn{2}{l}{ Change Statistic } & \\
\cline { 3 - 5 } & & & R square change & F change & Sig F change \\
\hline 0,483 & 0,233 & 0,218 & 0,233 & 15,496 & 0.000 \\
\hline
\end{tabular}

Berdasarkan analisis regresi berganda nilai $R$ sebesar 0,483 , nilai $\mathrm{R}^{2}$ sebesar 0,233 dan adjusted $\mathrm{R}^{2}$ sebesar 0,218 dengan taraf signifikansi sebesar 0,000 ( $p>0,05)$. Berdasarkan hasil tersebut, hipotesis yang diajukan dalam penelitian ini diterima. Artinya ada hubungan yang sangat signifikan antara regulasi emosi, konformitas teman sebaya dengan perilaku agresi. Sumbangsih secara bersama-sama sebesar 23,3\%. Selanjutnya, hasil uji hipotesis kedua adalah diterima dengan nilai t sebesar $-3,642$ dengan taraf signifikansi sebesar 0,000 ( $p>0,05)$.. Artinya ada hubungan yang sangat signifikan antara perilaku agresi dengan regulasi emosi. Korelasi yang ditunjukkan adalah korelasi negatif maka semakin tinggi regulasi emosi maka semakin rendah perilaku agresi. Hipotesis ketiga berlaku demikian yang disebut hipotesis diterima. nilai t sebesar 4,173 dengan taraf signifikansi 0,000 ( $\mathrm{p}<0,05)$. Berdasarkan analisis tersebut menunjukkan hipotesis yang diajukan dalam penelitian diterima. Artinya ada hubungan yang sangat signifikan antara perilaku agresi dengan konformitas teman sebaya. Korelasi yang ditunjukkan adalah korelasi positif maka semakin rendah konformitas teman sebaya maka semakin rendah perilaku agresi. Sumbangan efektif masing-masing variabel yaitu regulasi emosi memberikan sumbangan efektif sebesar 10,112\%, variabel konformitas teman sebaya sebesar $13,213 \%$. Sisanya 76,675\% ditentukan oleh faktor lain.

Persentase dari setiap variabel penelitian ikut mempengaruhi hasil penelitian ini yang digambarkan pada tabel 2 dibawah ini:

Tabel 2

Kategorisasi Variabel Penelitian

\begin{tabular}{llll}
\hline Kategori & Perilaku agresif & Regulasi emosi & Konformitas teman sebaya \\
\hline Tinggi & 0 & $22 \%(23$ siswa $)$ & $67 \%(69$ siswa $)$ \\
\hline Sedang & $35 \%(36$ siswa) & $61 \%(59$ siswa $)$ & $22 \%(23$ siswa $)$ \\
\hline Rendah & $65 \%(67$ siswa) & $19 \%(19$ siswa $)$ & $11 \%(11$ siswa $)$ \\
\hline
\end{tabular}

Tabel di atas menjelaskan bahwa secara umum perilaku agresif didominasi oleh kategori rendah kemudian disusul regulasi emosi kategori yang dominan adalah sedang. Nilai konformitas teman sebaya tinggi. Perolehan kategori sedang pada perilaku agresif pada 36 siswa dengan persentase $35 \%$. Kategori tinggi pada regulasi emosi adalah 23 siswa dengan persentase $22 \%$ dan nilai rendah adalah $19 \%$. Selanjutnya, variabel konformitas teman sebaya angka $23 \%$ merupakan penjabaran dari kategori sedang dan kategori rendah dijabarkan dengan $11 \%$ pada 11 siswa. Hasil penelitian ini menjelaskan bahwa terdapat hubungan negatif yang sangat signifikan antara regulasi emosi dengan perilaku agresi pada siswa SMK di Pontianak. Kemudian, ada hubungan positif yang sangat signifikan antara konformitas teman sebaya dengan perilaku agresi pada siswa SMK di Pontianak.

Daya diskriminasi aitem pada skala perilaku agresif berada pada kisaran $0,406-0,621$. Sebaran aitem favorabel yang dapat digunakan berjumlah 12 pernyataan dan semua aitem unfavorabel dianggap gugur sebab memiliki daya diskriminasi dibawah 0,300. Skala perilaku agresif sebanyak 12 aitem, beberapa aitem diantaranya sebagai berikut:

Tabel 3

Ringkasan Aitem Skala Perilaku Agresif Aitem

Jika saya marah saya akan mengamuk sendiri atau mengajak berantem orang Saya kesal melihat teman saya dekat dengan semua guru yang ada di sekolah Saya akan cemburu jika teman saya berpenampilan menarik perhatian orang lain Mengejek perasaan teman hal yang paling buruk 
5156 Hubungan Regulasi Emosi dan Konformitas Teman Sebaya dengan Perilaku Agresi di Pontianak - Sita Permatasari, Nina Zulida Situmorang, Triantoro Safaria

DOI: https://doi.org/10.31004/edukatif.v3i6.1422

Ketika saya kesal terhadap teman, saya lebih baik bercerita dengan orang yang

saya merasa nyaman

Ketika ada teman yang mengganggu, saya akan mengajak berkelahi

Dst....

Skala berikutnya pada regulasi emosi yang dimana daya diskriminasi aitem berada pada rentang 0,328 0,647. Sebaran aitem favorabel yang digunakan berjumlah 5 sedangkan aitem favorabel sebanyak 5 aitem. Skala regulasi emosi meliputi 10 aitem, beberapa aitem sebagai berikut:

\section{Tabel 4}

\section{Ringkasan Aitem Skala Regulasi Emosi}

Aitem

Saya tetap bersyukur meskipun mendapat nilai ulangan yang tidak memuaskan
Saya meminta maaf kepada orang lain karena telah melampiaskan amarah dan kekesalan kepadanya
Saya akan marah kepada orang yang tidak menepati janji tanpa memberi tahu saya terlebih dahulu
Saya mudah dendam dengan orang lain yang menyakiti perasaan saya
Saat sedang kesal, saya tidak tertarik untuk melakukan aktivitas apapun
Saya akan memperlihatkan kekecewaan kepada orang lain jika tidak mengikuti keinginan saya
Dst....

Daya diskriminasi aitem pada skala konformitas teman sebaya berkisar dari 0, $398-0,602$. Untuk skala konformitas teman sebaya tidak terdapat aitem yang gugur dengan perolehan 10 aitem favorabel dan 10 aitem unfavorabel artinya semua aitem dapat digunakan beberapa diantaranya:

\section{Tabel 5}

\section{Ringkasan Aitem Skala Konformitas Teman Sebaya}

Aitem

Saat kerja kelompok, saya sering mengikuti saran teman-teman kelompok

Saya akan melakukan sesuatu sesuai dengan apa yang diharapkan teman-teman terhadap saya, meskipun saya tidak mengharapkan hal yang sama

Saya akan percaya apapun yang di katakan teman, kemudian saya akan mengikuti perkataannya

Melanggar aturan sekolah adalah hal yang "menantang" selama saya melakukannyabersama teman-

teman

Saya akan melakukan sesuatu sesuai dengan apa yang diharapkan teman-teman terhadap saya, meskipun saya tidak mengharapkan hal yang sama.

Saya akan mengikuti aturan yang ada di lingkungan pertemanan saya.

Dst....

\section{Pembahasan}

Pada penelitian ini, terdapat tiga hipotesis. Hipotesis pertama, ada hubungan antara regulasi emosi, dan konformitas teman sebaya secara bersama-sama dengan perilaku agresi pada siswa SMK di Pontianak. Hipotesis kedua, ada hubungan negatif antara regulasi emosi dengan perilaku agresi pada siswa SMK di Pontianak. Hipotesis ketiga, ada hubungan positif antara konformitas teman sebaya dengan perilaku agresi pada siswa SMK di Pontianak. Analisis data memperoleh hasil bahwa ketiga hipotesis diterima yaitu hipotesis pertama, kedua, dan ketiga. Hasil analisis antara regulasi emosi dengan perilaku agresi menunjukkan bahwa ada hubungan negatif yang sangat signifikan antara regulasi emosi dengan perilaku agresi pada siswa SMK di Pontianak. Artinya semakin tinggi regulasi emosi maka semakin rendah perilaku agresi dan sebaliknya, semakin rendah regulasi emosi maka semakin tinggi perilaku agresif.

Penelitian yang dilakukan Rahmadhony (2020) mengungkapkan bahwa regulasi emosi membantu seseorang untuk mengubah pikiran negatif menjadi positif. Sehingga mempengaruhi emosi dan perilakunya, misalnya ketika seseorang mengubah pikirannya terhadap suatu stimulus negatif, kemudian mengatur dan menurunkan emosi negatifnya maka perilaku yang muncul adalah bentuk perilaku yang konstruktif, bukan destruktif. Regulasi emosi mempunyai tujuan untuk meminimalisir perilaku negatif dari masalah yang dihadapi dengan cara memonitor dan mengevaluasi pengalaman emosional (Young dkk, 2019). Menurut 
5157 Hubungan Regulasi Emosi dan Konformitas Teman Sebaya dengan Perilaku Agresi di Pontianak - Sita Permatasari, Nina Zulida Situmorang, Triantoro Safaria

DOI: https://doi.org/10.31004/edukatif.v3i6.1422

Schweizer dkk (2020) seseorang dengan regulasi emosi tinggi akan memiliki harga diri tinggi dan yang akan melakukan hal-hal yang positif dalam hidupnya. Sehingga, individu tidak menyalahkan dirinya sendiri ketika terjadi sesuatu yang tidak sesuai dengan keinginannya. Karena individu tersebut menghargai dan menerima kemampuannya.

Hasil analisis antara konformitas teman sebaya dengan perilaku agresi menunjukkan bahwa ada hubungan positif yang sangat signifikan antara konformitas teman sebaya dengan perilaku agresi pada siswa SMK di Pontianak. Artinya semakin rendah konformitas teman sebaya maka semakin rendah perilaku agresi dan sebaliknya semakin tinggi konformitas teman sebaya maka semakin tinggi perilaku agresi. Remaja yang mengalami emosi tidak stabil lebih mudah terjerumus karena mereka dapat dipengaruhi oleh tekanan kelompok dari lingkungan mereka (Tottenham dkk, 2011). Pada pertemanan, remaja memiliki tuntutan akan konformitas dan didalam lingkungan sosial yang beraneka ragam tersebut, kondisi kelompok pertemanan remaja memberikan pengaruh pada perilaku remaja (Prawitasari, 2011). Individu dan individu lainnya yang memiliki ikatan secara emosional cenderung akan membentuk kelompok baru. Sejatinya, konformitas kelompok telah bersepakat akan terus bersama-sama. Selain itu, tingginya intensitas dalam hal-hal tertentu seperti peniruan, penyesuaian, kepercayaan, kesepakatan, dan ketaatan menjadi satu kesatuan untuk membentuk kelompok. Ketika ada anggota kelompok merasa terganggu oleh orang lain, maka kecenderungannya adalah menghampiri kemudian berbicara dengan orang tersebut. Konformitas dalam penelitian ini tergolong tinggi dan tingkat agresivitasnya rendah yang berarti bahwa budaya-budaya yang terbangun dalam kelompok tersebut adalah positif dan tidak saling merugikan. Justru saling mendukung dan saling merangkul.

Beberapa siswa terlihat memukuli, menendang dan aktivitas yang mengarah pada perilaku agresi fisik. Ketika agresi fisik dipraktikkan maka akan timbul agresi-agresi susulan yang membuat orang lain maupun lingkungan sekitar ketidaknyamanan. Agresi susulan lainnya seperti berbicara dengan bahasa yang kurang sopan, meneriaki dengan keras guru ataupun teman, menatap sinis orang lain, mengejek, mengungkit-ungkit kesalahan orang lain di depan umum, dan lain sebagainya. Ungkapan ini selaras dengan hasil penelitian Martínez-González dkk (2021) yang menyebutkan bahwa agresi dipengaruhi oleh faktor psikologis siswa yang dimana perempuan lebih dominan melakukan tindakan agresi. Penyebabnya adalah anak perempuan memiliki kecemasan, depresi stress maupun perasaan yang lebih emosional, takut ditinggalkan oleh temantemannya dan takut dilabel tidak setia kawan sehingga ia bertindak agresif dibandingkan dengan siswa lakilaki. Tindakan ini dinilai sebagai bentuk katarsis untuk melepaskan pengaruh dari perasaan-perasaan negatifnya.

Penyelesaian masalah dengan cara marah membuat individu dapat diredam dengan mengontrol emosi. Sikap marah yang berlebihan dapat berdampak buruk pada keberlangsungan kehidupan sosial. Individu mampu mengatasinya dengan cara yang lebih baik seperti menahan emosi negatif dan menyebarluaskan emosi positif. Dalam penelitian Zawati dkk (2020) tindakan agresif dapat menurun dengan pemberian reward dan punishment. Reward dan punishment adalah salah satu cara untuk mengendalikan dan melatih emosi agar tidak meluap-luap dan individu paham akan situasi yang mengharuskannya berbuat positif atau berbuat agresi. Agresi yang tergolong rendah menunjukkan bahwa permusuhan jarang terjadi di Pontianak. Dugaan awal yang menyebutkan terjadi permusuhan tidak dapat digeneralisasikan. Sebagian besar siswa saling berteman baik sehingga jarang terjadi permusuhan. Sesuai dengan prediksi Palinoan dkk (2015) bahwa pada tahap perkembangannya, remaja dituntut untuk dapat menyesuaikan diri secara efektif dengan lingkungan sosial tempat mereka berinteraksi baik terhadap individu, kelompok, maupun dengan lingkungan sekitar. Individu mengakui adanya persahabatan dan sebagian besar kelompok menyetujui persahabatan demi kebaikan bersama. Individu membutuhkan bimbingan baik dari keluarga maupun teman agar intensitas agresinya berkurang (Raman and Tohari 2021). 
Terdapat bukti empiris bahwa individu yang memiliki regulasi emosi yang tinggi cenderung mampu mengatur emosinya secara sehat (Roberton dkk, 2012). Regulasi emosi dapat menjauhkan individu pada emosi negatif sebab ia mampu mentolerir dan menahannya. Selain itu, regulasi sama halnya dengan sadar akan emosi-emosi positif kemudian menjadi perilaku adaptif. Ketika muncul masalah, individu berpikir dengan jernih dan mampu mengatasinya dengan baik. Pilihannya adalah menghapus atau menghindari stressor dari lingkungan atau memperbaiki efek dari lingkungan. Bahkan, etika ikut tergerus oleh dampak agresi. Individu diharapkan mencermati hal-hal buruk dan memperbaiki etikanya dalam berkomunikasi dengan orang lain (Rasimin dkk, 2021). Individu tentunya harus memilih langkah yang efektif yakni mengatur atau meregulasi emosinya dengan melibatkan emosi-emosi positif dan coping stress yang sesuai. Sama halnya dengan korban, regulasi yang ditanamkan seperti berdiam, menangis, menggerutu, dan memarahi pelaku bullying (Wardah 2020).

Kondisi yang tidak memungkinkan membuat peneliti harus bertindak dengan metode yang di luar dugaan. Pada masa pandemi, banyak aktivitas yang dibatasi termasuk sekolah tatap muka dan penelitian tata muka. Oleh karena itu, kekurangan atau kelemahan yang disadari oleh peneliti yaitu pada saat melakukan penelitian, peneliti tidak dapat bertatap muka dengan subjek secara langsung keran situasi pendemi covid 19 yang mengharuskan semua penelitian dilakukan secara online. Kurangnya kesempatan bagi subjek untuk bertanya secara langsung mengenai kuesioner yang diberikan sehingga memunculkan persepsi-persepsi yang berbeda. Peneliti tidak mampu memberikan penjelasan lebih detail namun penelitian ini disusun sesuai dengan kaidah dan menggunakan bahasa sederhana agar mudah dipahami oleh subjek. Google form menjadi aplikasi yang digunakan untuk penelitian ini. Jika ditinjau dari jumlah sampel, maka dapat dikatakan masih sedikit. Sampel tidak mewakili seluruh pelajar di Pontianak sebab peneliti menfokuskan pada pelajar yang bersekolah di sekolah kejuruan. Upaya untuk memperoleh sampel penelitian yang lebih banyak perlu dilakukan pada penelitian berikutnya agar hasil penelitian tersebut dapat lebih bermanfaat untuk masyarakat secara luas. Penelitian bermula dari adanya keresahan atas masalah di lingkungan sekitar. Ke depannya, peneliti diharapkan mengkaji dan lebih menggali masalah yang akan diteliti. Selain itu, setiap skala penelitian hendaknya tidak ada aitem yang gugur baik itu favorabel maupun unfavorabel. Hasilnya dalam penelitian ini terdapat aitem unfavorabel yang semuanya gugur khususnya pada skala perilaku agresi. Skala perilaku agresi hanya memiliki aitem favorabel dan tidak didukung dengan aitem unfavorabel.

\section{KESIMPULAN}

Penelitian ini menunjukkan bahwa memiliki regulasi emosi yang sedang dapat menurunkan perilaku agresi dan ketika konformitas teman sebaya tinggi dapat menurun perilaku agresi pada siswa. Oleh karena itu, terdapat saran praktis bagi orang tua siswa, siswa sekolah, dan pihak sekolah. Kepada kedua orang tua siswa diharapkan untuk lebih meluangkan waktu untuk sharing atau mendengarkan cerita anak seusai pulang sekolah, agar anak terbiasa bercerita dan orang tua dapat membimbing perilaku anak di lingkungan sekolah. Dengan membangun komunikasi yang baik maka anak dapat terbentuk perilaku positif dan dapat terhindar dari perilaku agresi. Untuk siswa diharapkan jika mengalami kendala atau masalah di sekolah yang tidak bisa diselesaikan sendiri, diharapkan untuk bercerita kepada guru BK atau wali kelas agar guru yang bersangkutan dapat membantu memberikan saran dan membimbing. Untuk sekolah, diharapkan lebih mengawasi perilaku yang dilakukan siswa saat disekolah, bijaksana dalam mendengarkan keluh kesah siswa, dan sekolah juga diharapkan untuk memberikan informasi kepada orang tua terkait perilaku siswa di sekolah, agar terjalin komunikasi yang baik antar siswa, orang tua murid, pihak sekolah. Siswa dapat mengembangkan konformitas di dalam kelompoknya dengan melakukan kegiatan-kegiatan positif seperti ikut serta dalam setiap lomba, membantu bapak/ibu guru, membuat konten-konten kreatif untuk memajukan sekolah, meraih cita-cita dan tetap berperilaku rendah hati kepada setiap orang. 
5159 Hubungan Regulasi Emosi dan Konformitas Teman Sebaya dengan Perilaku Agresi di Pontianak - Sita Permatasari, Nina Zulida Situmorang, Triantoro Safaria

DOI: https://doi.org/10.31004/edukatif.v3i6.1422

\section{UCAPAN TERIMA KASIH}

Peneliti mengucapkan terimakasih kepada seluruh pihak-pihak yang berkontribusi diantaranya Kepala Sekolah SMK N 3 Pontianak, Kepala Sekolah SMKN 5 Pontianak, Bapak/Ibu guru, serta saling memberikan feedback demi kelancaran penelitian ini.

\section{DAFTAR PUSTAKA}

Azwar, Saifuddin. 2009. "Efek Seleksi Aitem Berdasar Daya Diskriminasi Terhadap Reliabilitas Skor Tes." Buletin Psikologi 17(1):28-32. doi: 10.22146/bpsi.11479.

Azwar, Saifuddin. 2015. “Asumsi-Asumsi Dalam Inferensi Statistika.” Buletin Psikologi 9(1):8-17. doi: 10.22146/bpsi.7436.

Fitri, Susi, Meithy Intan Rukia Luawo, and Dewi Puspasari. 2016. "Gambaran Agresivitas Pada Remaja LakiLaki Siswa SMA Negeri Di DKI Jakarta.” Insight: Jurnal Bimbingan Konseling 5(2):155. doi: 10.21009/insight.052.02.

Li, Zhenhua, Chengfu Yu, and Yangang Nie. 2021. "The Association between School Climate and Aggression: A Moderated Mediation Model."

Martínez-González, Marina B., Yamile Turizo-Palencia, Claudia Arenas-Rivera, Mónica Acuña-Rodríguez, Yeferson Gómez-López, and Vicente J. Clemente-Suárez. 2021. "Gender, Anxiety, and Legitimation of Violence in Adolescents Facing Simulated Physical Aggression at School." Brain Sciences 11(4). doi: 10.3390/brainsci11040458.

Noviadi, Randy, Tri Esti Budiningsih, and Nuke Martiarini. 2018. “Agresivitas Remaja Di Sekolah Menengah Atas Swasta Kabupaten ??X?” Intuisi : Jurnal Psikologi Ilmiah 10(1):79-88. doi: 10.15294/intuisi.v10i1.17389.

Palinoan, Erick Lolang, Program Studi Psikologi, and Universitas Mulawarman Samarinda. 2015. "Kelompok Geng Motor Di Samarinda.” 3(2):173-85.

Prasetio, Novadri, Muh Daud, and Andi Nasrawati Hamid. 2021. "Hubungan Regulasi Emosi Dengan Bullying Pada Siswa Kelas XII SMA Negeri 2 Makassar." JIVA: Journal of Behavior and Mental Health 2(1):144-54.

Pratiwi, Hapsari Dian, Nina Zulida Situmorang, and Yuzarion. 2019. "Gambaran Agresivitas Remaja." Prosiding Seminar Nasional Magister Psikologi Universitas Ahmad Dahlan (2):227-33.

Prawitasari, J, E. 2011. Psikologi Klinis Pengantar Mikro Dan Makro. Jakarta: Erlangga.

Prayugo, Muchammad Inggit, and Suroso Suroso. 2018. "Hubungan Konsep Diri Dan Konformitas Teman Sebaya Dengan Perilaku Agresif Remaja." PSIKOSAINS (Jurnal Penelitian Dan Pemikiran Psikologi) 13(1):33. doi: 10.30587/psikosains.v13i1.345.

Purwadi, Purwadi, Said Alhadi, Agus Supriyanto, Wahyu Nanda Eka Saputra, Siti Muyana, and Amien Wahyudi. 2020. "Aggression among Adolescents: The Role of Emotion Regulation." HUMANITAS: Indonesian Psychological Journal 17(2):132. doi: 10.26555/humanitas.v17i2.7719.

Puspawardhani, A. 2021. "Pengaruh Pengendalian Emosi Dan Kemampuan Komunikasi Interpersonal Terhadap Agresivitas Antar Teman Sebaya Pada Siswa Kelas Viiii Di Sekolah Menengah Pertama Muhammadiyah Kasihan." G-COUNS: Jurnal Bimbingan Dan Konseling 5(2):177-83.

Rahmadhony, Samurya. 2020. "The Effectiveness of Emotion Regulation Training to Reduce Bullying Behavior in Middle School Students." Analitika: Jurnal Magister Psikologi UMA 12(2):169-78. doi: //doi.org/10.31289/analitika.v12i2.3733.

Raman, Ainur, and Begjo Tohari. 2021. "EDUKATIF: JURNAL ILMU PENDIDIKAN Penerapan Bimbingan Konseling Berbasis Buku Poin Dalam Membina Kedisiplinan Peserta Didik Di Madrasah Aliyah.” 3(5):3361-70. 
5160 Hubungan Regulasi Emosi dan Konformitas Teman Sebaya dengan Perilaku Agresi di Pontianak - Sita Permatasari, Nina Zulida Situmorang, Triantoro Safaria

DOI: https://doi.org/10.31004/edukatif.v3i6.1422

Rasimin, Rasimin, Affan Yusra, and Hera Wahyuni. 2021. "Penerapan Bimbingan Belajar Berbasis PrinsipPrinsip Belajar Dalam Islam Untuk Meningkatkan Etika Belajar Siswa." Edukatif: Jurnal Ilmu Pendidikan 3(2):321-32. doi: 10.31004/edukatif.v3i2.262.

Raviyoga, Tarate Timur, and Adijanti Marheni. 2019. "Hubungan Kematangan Emosi Dan Konformitas Teman Sebaya Terhadap Agresivitas Remaja Di SMAN 3 Denpasar." Jurnal Psikologi Udayana 6(01):44. doi: 10.24843/jpu.2019.v06.i01.p05.

Retnowuni, Arifa, and Athi Linda Yani. 2019. "Faktor-Faktor Yang Mempengaruhi Perilaku Agresif Pada Remaja Yang Tinggal Di Pesantren." Journal of Holistic Nursing Science 6(1):36-43. doi: 10.31603/nursing.v6i1.2406.

Roberton, Terri, Michael Daffern, and Romola S. Bucks. 2012. "Emotion Regulation and Aggression." Aggression and Violent Behavior 17(1):72-82. doi: 10.1016/j.avb.2011.09.006.

Schweizer, Susanne, Ian H. Gotlib, and Sarah Jayne Blakemore. 2020. "The Role of Affective Control in Emotion Regulation during Adolescence." Emotion (Washington, D.C.) 20(1):80-86. doi: 10.1037/emo0000695.

Sentana, Mohammad Arif, and Intan Dewi Kumala. 2017. "Agresivitas Dan Kontrol Diri Pada Remaja Di Banda Aceh.” Jurnal Sains Psikologi 6(2):51-55. doi: 10.17977/um023v6i22017p051.

Sovitriana, Rilla, Hardiyanti Christina Sianturi, and Universitas Persada Indonesia Y. A. I. 2020. "Kematangan Emosi Dan Konformitas Teman Sebaya Dengan Perilaku Agresif Pada Remaja Di Kelurahan X Kabupaten Bekasi Abstrak Jurnal IKRA-ITH Humaniora Vol 5 No 2 Bulan Juli 2021.” Universitas Persada Indonesia Y.A.I 5(74):118-26.

Thohar, Syafruddin Faisal. 2018. "Pengaruh Mindfulness Terhadap Agresivitas Melalui Regulasi Emosi Pada Warga Binaan Lembaga Pembinaan Khusus Anak Kelas I Blitar.” Journal at Psychology and Islamic Science 2(1):27-50.

Tottenham, Nim, Todd A. Hare, and B. J. Casey. 2011. "Behavioral Assessment of Emotion Discrimination, Emotion Regulation, and Cognitive Control in Childhood, Adolescence, and Adulthood." Frontiers in Psychology 2(MAR):1-9. doi: 10.3389/fpsyg.2011.00039.

Trisnawati, J., A. Nauli, F, and Agrina. 2014. "Faktor-Faktor Yang Mempengaruhi Perilaku Agresif Remaja Di SMKN 2 Pekanbaru." Jurnal Ilmu Keperawatan 1(2):1-9.

Wardah, Ani. 2020. "Keterbukaan Diri Dan Regulasi Emosi Peserta Didik SMP Korban Bullying." Indonesian Journal of Learning Education and Counseling 2(2):183-92. doi: 10.31960/ijolec.v2i2.410.

Young, Katherine S., Christina F. Sandman, and Michelle G. Craske. 2019. "Positive and Negative Emotion Regulation in Adolescence: Links to Anxiety and Depression." Brain Sciences 9(4). doi: 10.3390/brainsci9040076.

Zawati, Efi, Ayi Teiri Nurtiani, Universitas Bina, and Bangsa Getsempena. 2020. "Penggunaan Metode Reward Dan Punishment Dalam Mengurangi Perilaku Agresif Pada Anak Usia 4-6 Tahun Di TK." Jurnal Ilmiah Mahasiswa 1(1):1-12. 